Article

\title{
On-Site Sewage Systems from Good to Bad to...? Swedish Experiences with Institutional Change and Technological Dependencies 1900 to 2010
}

\author{
Are Wallin ${ }^{1}{ }^{*}$, Mathias Zannakis ${ }^{2}$ and Sverker Molander ${ }^{1}$ \\ 1 Department of Energy and Environment, Chalmers University of Technology, Gothenburg SE-412 96, \\ Sweden; E-Mail: sverker.molander@ chalmers.se \\ 2 Department of Political Science, University of Gothenburg, P.O. Box 711, Gothenburg SE-405 30, \\ Sweden; E-Mail: mathias.zannakis@pol.gu.se
}

* Author to whom correspondence should be addressed; E-Mail: are.wallin@ chalmers.se; Tel.: +46-31-772-5644; Fax: +46-31-772-2172.

Received: 8 July 2013; in revised form: 24 October 2013 / Accepted: 25 October 2013 /

Published: 7 November 2013

\begin{abstract}
Even though technological advances have occurred during recent decades today's nutrient loading from Swedish on-site sewage systems (OSSs) is much higher than in the 1940s, despite a decreased rural population and the existence of potentially far better technologies than the existing inadequate installations. The objective of this paper is first, to explain this situation as the result of co-evolution of technology and institutions, which has resulted in a very stable conservation. Second, to properly understand how such stable configurations may change, the paper investigates how a power-distributional theory of incremental institutional change might complement the previous analysis and open up the thinking about how seemingly stable configurations may change endogenously. The analysis reveals how shifts in the distribution of power, i.e., public and private actors' resources and tools to use in interaction with other actors, have influenced the direction of technological and institutional development. We conclude that the sequencing of events has been important; the series of choices made foremost between the 1950s and 1990s caused both institutional and technical lock-in effects that have been increasingly difficult to break out from. Despite parallel and later incremental developments, improvement in the environmental outcome is not yet seen on the large scale.
\end{abstract}


Keywords: sewage water; incremental institutional change; technological dependency; environmental pressures; path dependency

\section{Introduction}

The large-scale application of new technologies for the provision of basic services, such as transportation and sanitation, has been made with the best intentions and enabled industrialization, urbanization, a greater human population and increased welfare. However, over time, environmental impacts have become huge "unintended consequences" and a driving force for further development. This is certainly the case for systems providing clean water and treatment of sewage in urban and rural settings. The expansion of piped water and sewage first occurred in cities and, later from the mid-20th century onwards, in the scattered rural settlements of Sweden [1]. Their benefits included improved hygiene in homes but they have, over time, been increasingly recognized as a cause of eutrophication, due to their nutrient-rich effluents and their increasing loads relative to other contributing sources [2,3].

In this paper we analyze the Swedish case to illustrate the wider problem of the use of on-site sewage systems (OSSs) and historical processes through which society has been "locked-in" to water-based transport and further handling of excreta. By OSSs we refer to a number of types of sewage treatment systems serving one or a few households. In Sweden about 700,000 permanent homes are equipped with OSSs, of which half are deemed to have poor performance and be deficient compared to demands of the current legislation [3-5]. Moreover, the poor performance of Swedish OSSs has been recognized in legislation since at least the late 1960s, but without substantial effects in the technologies applied [6]. Today, the total nutrient emissions from OSSs are almost as high as those of urban wastewater treatment plants even though the all-year-round-users of OSSs are only about one seventh of the Swedish population [7], and see Supplementary Material Table S1. About 15\% of Swedish phosphorous loads originate from this source [3,5].

The increasing nutrient loads of Swedish OSSs can be traced to the large-scale expansion of the water closet (WC) and the consequent application of early water-based treatment technologies between the 1940s and the 1970s. Nearly all countryside homes were retrofitted with new water and wastewater systems during this period. Since the technologies used were poor from a nutrient capture point of view the loads to ground and surface waters increased, illustrated in Figure 1. Thereafter, despite the fact that the environmental problems associated with OSSs have long been known and more efficient technologies have been around since at least the 1970s, they have not been applied. Consequently, the nutrient capture capability of the Swedish stock of OSSs has not improved since then and the decreasing nutrient load trend has stagnated. Even though the countryside population was much larger in the 1940s the total nutrient loads are higher today.

The change of on-site sewage treatment technology over time can be understood as a case of socio-technical change, implying that both technical as well as social factors, and actors, are incorporated in the analysis. We depart from the multi-level perspective (MLP) on technological transitions [8,9], acknowledging that the application of new technologies needs to be understood in relation to change processes at different levels of societal analysis. Changing such large-scale socio-technical systems are 
the results of processes in broader society, of specific actions taken at different levels as well as emergent behaviors of actors at different system levels. Among the acknowledged weak points of the MLP are the incorporation of agency and multi-regime interaction as a source of regime change [10]. Recent developments in institutional theory [11] propose an alternative view on institutional change that is based on the conception that compliance with institutions varies along a continuum rather than an either/or situation, and that institutions bring with them certain distributions of power among actors. This is a plausible way to address some of the critique. Explanations to varying degrees of compliance are found in the space of action formed by the rule and its interpretation or enforcement, and the extent that actors playing the role as institution-defenders have in the possibility to resist change. Thus, institutional character and political context are key factors affecting the pattern of institutional change.

Figure 1. Estimated per capita (A) and total (B) loads of phosphorous and nitrogen from Swedish on-site sewage systems (OSSs) 1945-2010. Assumptions and calculations are attached as Supplementary Material.

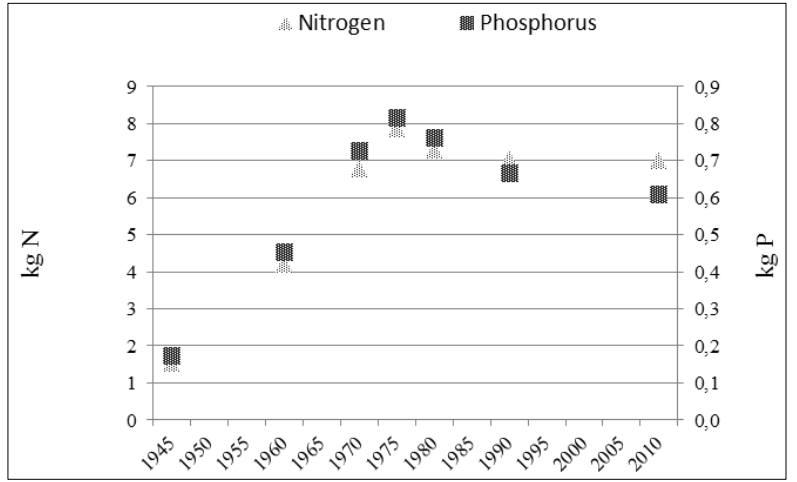

(A)

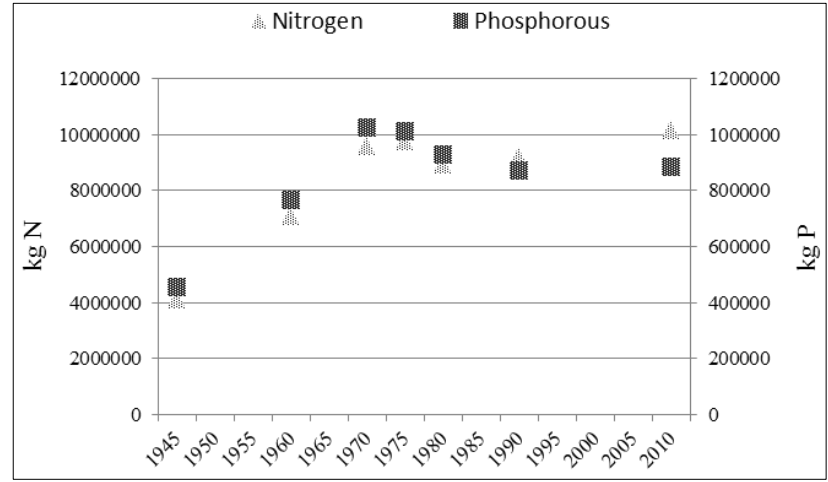

(B)

On a general level we consider the slowly moving socio-technical "landscape", the mind-set of influencing actors and what they find feasible and possible to do. Then we analyze "regime" level processes, i.e., the assemblage of relevant actors for the issue at hand and the set of rules that coordinate them. In particular, we investigate the institutional dimension of transitions [11-14], interpreting the situation through the perspective of incremental institutional change according to Mahoney and Thelen [11]. In addition, we discuss change processes that have led to improved environmental outcomes and those that do not. One lesson of historical transitions is that the important criteria for users in past transitions are not necessarily those that will lead the way to more sustainable states [15], which would possibly suggest that future transitions are only partly reliant on users taking on new criteria for the choice of technology.

The aim of this study is thus, firstly, to describe the historical development of OSS and the associated, mostly increasing, nutrient loads. Secondly, we explain this mostly negative load trend by the co-evolution of technology and institutions, which has become a very stable configuration. We are interested particularly in identifying not only the factors that have contributed to transformation of the technological system but also the factors that have impeded improved environmental outcomes, factors that are possibly still operating. Thirdly, we introduce a power-distributional theory of institutional change and suggest, that as an important complement to the previous MLP analysis of 
socio-technical change, this opens up thinking about how such seemingly stable configurations may change endogenously.

In the studied case we identify three eras with distinctly different socio-technical regimes with technological and environmental implications. The first era begins in the early 20th century, though most activities that directly feed technological and environmental change appear from the 1940s, and resulted in a large-scale introduction of piped water and to a large extent also the water closet (WC). The second era begins in the 1960s, largely characterized by the discovery of environmental problems and the institutionalization of water-based treatment technologies. The third era begins in the early 1990s, when sustainable development and resource problems were increasingly discussed, and thus implies increasing awareness that technological change was not occurring to a sufficient extent and pace to substantially mitigate nutrient loads. The treatment potential of the hitherto dominant technology is increasingly questioned [16]. In this recent period, there are indications of larger-scale environmental improvements of existing OSSs because of strengthened formal institutions (stricter rules and active enforcement), especially in the last decade. However, the new rules of the last era can be flexibly interpreted something that, together with a political context in which market solutions are increasingly promoted, alter the power balance between regulative actors and market actors in favor of the latter group.

The paper is organized as follows. In Section 2 we describe the theoretical background of the paper, consisting of the MLP and insights from historical institutionalism's analysis of incremental change processes. Section 3 briefly describes the data and methods. In Section 4, the development of Swedish OSSs is described in three eras, each characterized by its institutional-technological changes. In the last Section we discuss how to understand periods of seemingly stable socio-technical configurations and the complementarity view on institutional change, and discuss furthermore some implications for the contemporary management of OSSs.

\section{Theoretical Frameworks Used to Interpret the Historical Development}

In order to understand the processes and patterns of technological and institutional stability and change we use the literature on the MLP, focusing on processes at the regime level, e.g., [8,12]. The MLP [8,9,12] captures processes crossing scales (e.g., time, space, administrative, judicial) and system levels explaining the dynamics of socio-technical change. The elements of the studied system are heterogeneous, consisting of actors, such as actors using, regulating or developing technologies, of institutions (i.e., regulative, normative, cognitive) that coordinate actors, and of the more tangible elements of the socio-technical (ST) system, for example, artifacts, knowledge of engineers developing a technology, symbolic meaning attached to particular technologies, or, scientific knowledge.

Three levels of analysis are identified as important in understanding change dynamics [8,12]. At the level of the socio-technical landscape, fixed or slow-moving technology-external processes are operating that are beyond the direct influence of the regime actors, at least in a short-term perspective. Processes at the landscape level provide the context for lower levels and the landscape level is comprised of for example macro-economy, physical infrastructures, geographical differences in climate and soils, and cultural values. Such processes influence the mind-set of actors and what they find feasible and possible to do. The level of the socio-technical regime highlights the importance of 
intra and intergroup coordination that occurs around the dominant technologies. This coordination is played out under certain institutions that define the rules for actors. Because institutions are shared across various groups and they become intertwined with the elements of the socio-technical system, processes at the regime level explain periods of stability. Finally, at the niche level novelties may emerge, i.e., new configurations of actors, institutions and ST system components which are more or less in conflict with current configurations at the regime level. Niches offer relatively protected spaces where novelties can be nurtured until they are sufficiently fit to influence the regime [8,12].

The MLP has been useful for explaining various technological transitions, but has also been criticized [10,17], e.g., for the lack of agency, i.e., the understating of the contribution of agents to institutional change or stability at the regime level. We view institutions as more or less continuously undergoing change, and acknowledge that actors change institutions from within the regime. Further, the MLP had too much focus on single regimes, while multi-regime interaction may be an important source of change. As we suggest throughout our case study, actors may derive their power because of their position vis-à-vis an institution in one context and they can utilize this power to influence the direction of change of a socio-technical system and institutional change in another context.

When explaining institutional change we draw on the power-distributional approach to institutions proposed by Mahoney and Thelen, who are primarily influenced by historical institutionalism [11]. Institutions are broadly defined as "relatively enduring features of political and social life that structure behavior" ([11], p. 4), which includes rules, norms and procedures but counts also cognitive dimensions such as scripts that guide behavior in certain communities. The definition of institutions in the transitions literature, e.g., $[8,12]$ is thus similar to this definition. Mahoney and Thelen search for an all-encompassing theory of incremental institutional change that captures both exogenous and endogenous sources of change. The basic view is that institutions have implications in terms of distributions of roles, resources, and tools, which put certain actors in the position to exert power over other actors. The fact that institutions do this is a source of conflict, because actors will be differently constrained in their activities. Institutional stability is therefore explained by periods of lasting "compromises" or dominant actors that are able to maintain their position or adjust the institutions in line with their interests.

Such lasting "compromises" are expressions of institutional change processes being path dependent - they are "social processes that exhibit positive feedback and thus generate branching patterns of historical development" ([13], p. 21). Positive feedback mechanisms results in developments in which "the probability of further steps along the same path increases with each move down that path" (ibid.) - it becomes costly to change direction and choose a direction that seemed possible at an earlier point in time. As shown in studies of socio-technical systems such costs have to do with the high connectivity of social and technological aspects, e.g., when a technology is widely spread it is also connected to a heterogeneous set of elements such as know-how among engineers, user practices, and built infrastructures [8]. This implies a narrowed horizon of possibilities, i.e., a chosen path empowers some actors to protect, for themselves, a favorable status quo [13,14,18]. In order to understand the historical processes one must focus on events and sequences that lead to institution-building and institutional change - the many small events, spread over time, that bend the development path. The sequencing of these events is important, not least since they may have unintended but important and long-term consequences. 
Other sources of change are related to the fact that rules are very seldom free from interpretation during implementation and are therefore seldom fully enforced [11]. Thus, there will always be a gap between the intentions formulated in rules and the outcomes in reality due to vagaries of interpretation and enforcement, leading to unintended outcomes and, over time, ignored and replaced rules. Based on this understanding, Mahoney and Thelen's [11] model explains incremental institutional change by linking different change modes with the political/institutional context, and institutional actors' level of discretion in interpretation and enforcement. Certain actors derive power from institutions because institutions assign roles and resources and provide tools to use in interaction with other actors. Further, the model identifies defenders of the institutions and the extent that they are given power or by other means have the ability to maintain an institutional status quo, something that is termed "to have veto possibilities". Importantly, actors may use their position vis-à-vis others, given by one institutional context in another institutional context, playing partly separate games that suit their overall interests. In the analysis it is important to look for shifts in the power balance between actors. The type of actors active in institutional change can be characterized by whether they "seek to preserve institutions" and whether they actually follow the rules.

This perspective on institutions is complementary to the MLP. The weakness of Mahoney and Thelen's approach to institutional change, from the viewpoint of this paper, is that it does not explicitly include socio-technical system elements in the analysis. Clearly, such elements also constrain change, imposing restrictions on what actors can do and here we seek to combine these approaches.

\section{The Handling and Management of Sewage and Wastewater in Sweden 1900-2010}

There are limited accounts of the history of Swedish OSS already available. The sources used, to delineate the development of Swedish OSS, include primary sources such as official statistics, government agency inquiries, and technical reports. Other historical descriptions of rural and urban living have been used as well although these have only partially covered OSS. By contrasting these various sources through data triangulation, the history of events in the case of Swedish OSS has been uncovered. The MLP has been used to structure the development of OSS identifying processes at foremost landscape and regime levels. The theory of incremental institutional change led to a slightly different interpretation with its emphasis on identifying flexibility in the interpretation of rules and the ability of different actors to maintain and change institutions as sources of incremental institutional change. The data and assumptions used to create the graphs on historical nutrient loads and emerging OSS are described in detail in Supplementary Material.

\subsection{Hygiene Concerns and a Growing Demand for Comfortable Living Drive a Large-Scale Rural Expansion of Piped Water and Wastewater in the 1940s-1960s}

At the turn of the 20th century, a very small share of the rural population had piped water and/or wastewater or WC. Latrines were emptied on the dunghill together with animal excrements and spread on the farmland. Water, mainly for cooking purposes, was carried into the houses and wastewater was carried out and thrown in gardens or into the nearest ditch. In terms of nutrient recovery and cycling, this system was likely to have been very efficient. The application of this solution started to change after a few decades into the century and by the early 1940s about a third of the rural population had 
piped water and wastewater [19]. However, only around five per cent had bathroom and WC installed suggesting that the nutrient-rich fraction of the sewage was handled the traditional way.

In order to understand these developments we have to go back to the major transformation of the urban handling of water, wastewater, and sewage starting in the second half of the 19th century when the city populations grew. The cities of the time experienced recurring epidemics of, e.g., cholera, because of their rudimentary handling of wastes in general [20], and sewage in particular [21]. Cities started to install water pipes to improve the situation regarding polluted wells. Different systems for handling the excreta were tested with the purpose of improving hygienic conditions and pleasantness of urban living. The bucket system implied that, e.g., farmers in the periphery of the cities transported and got rid of buckets of excreta in different ways. In the second half of the 19th century a system for fertilizer production using excreta and chalk was operating in Gothenburg (production of so called poudrettes), but this system did not become the large-scale solution for the 20th century [20]. In order to promote change, the government instituted the Health Protection Regulation in the 1870s, which regulated the construction of toilets, the handling of sewage and latrines. At the end of the 19th century water and wastewater pipes were installed and water toilets were applied on a larger scale. The situation improved drastically with regard to hygiene. A few decades into the 20th century $90 \%$ of the urban households were connected to water and wastewater systems, of which a majority had WCs [19].

Compared to the situation in the cities the countryside was lagging behind. Even though the health situation and the occurrence of epidemics cannot have been as bad in the countryside as it was in the cities several decades earlier, there were certainly calls for action to relieve the people in the countryside from their poor living conditions [22]. The lifestyle of the rural population was not coming anywhere near to the modern lifestyle that the urban population enjoyed at the time [23]. However, since many people were poor and thus had other pressing problems to think of, at least initially they may not have perceived the benefits of piped water and the WC. Nevertheless, it is likely that a majority of the people very soon aspired to WCs, since they must have been perceived as a convenient alternative to the latrines [22,24]. On a national governmental level the issue of the neglected countryside was also acknowledged [25]. The steps taken already by the state to improve the living conditions in general, supporting the introduction of central heating and more spacious apartments, also came to include improvements to hygienic conditions. Thus, the idea of improved hygiene in countryside homes seems to originate to a large extent from the urban upper and middle classes who already were experiencing higher living conditions, although this with time probably also represented the views of many in the countryside.

To stimulate change the national government funded large-scale home improvement programs during the decades before and after World War II. One of the main purposes of the reforms of the 1940s was health promotion [6,26], emphasized by the fact that the main responsibility of inquiry and planning was at the Health Protection Agency [26]. A reason for initiating these programs was that the industry needed workers, and the state helped out by stimulating the building of homes closer to the industries and by promoting sound home environments. Taxes from workers in turn also gave the state revenues to spend on the reforms. The home improvement activities in themselves in addition created jobs. Although the programs focused on cities and population centers they also covered the countryside. In terms of stimulating change of water and sewage handling, it seems to have been 
particularly the government interventions after World War II that influenced the transformation to foremost piped water and wastewater. The subsidy programs for the installation of water and wastewater systems were relatively generous. Through the inquiry and proposition in 1942 home-owners could receive a subsidy of SEK 200 - the costs of investing in piped water and wastewater ranged from SEK 210-865 [25]. The already existing municipal health protection committees came to administer the subsidies and loans linked to the general home improvement activities (in Swedish Allmänna bostadsförbättringsverksamheten), including the subsidies and loans for the installation of water wells and piped water and wastewater. The subsidy program was expanded in 1949, after an initiative of the Swedish National Institute for Public Health, which led to an increase in state funding of both urban and rural water and wastewater systems [26]. The following state inquiry into small-scale sewage systems (in Swedish 1950 års avloppsutredning) in 1944-1955 [27] resulted in further increased state-funding. During the second half of the 1950s, the state prioritized household connection to water and wastewater systems, either through local and individual solutions or cooperative or municipal solutions. Funding increased multi-fold, in the last three years of the decade from SEK 200-600 million [26]. The expansion of piped water and wastewater systems and WCs in the countryside homes was distinct during the late 1940s and the 1950s, as Figure 2 illustrates. About 250,000 water and wastewater systems and 200,000 WCs were installed in the countryside during this time period.

Figure 2. The expansion of piped water and wastewater systems, baths/showers and WCs into Swedish countryside permanent homes 1945-2010 [1].

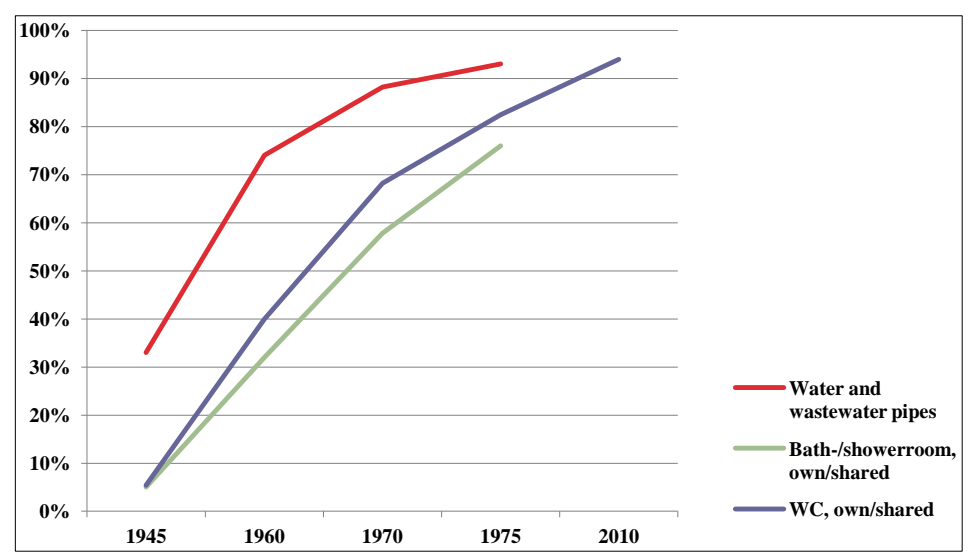

Other, landscape level, processes also had an influence on the transformation of OSSs. The urbanization "pull" of industrialization processes, providing opportunities for employment, as well as a combination of high rural nativity and limited agricultural land, implying a limited opportunity to earn a living from the land when the land was divided into smaller parcels, also "pushed" people from the countryside. This led to the abandoning of many countryside homes and also implied the end of old OSSs and traditional waste handling systems [28]. The emigrants from the countryside to the cities also very likely brought with them the lifestyles of the cities when they returned for visits, contributing to the change of norms regarding sanitary facilities. We speculate this contributed to the process of making WCs the desirable solution. 
The OSS rules of the time did not spell out any constraints regarding how to arrange the handling of sewage in the countryside. In fact, already at this time the existing rules for handling wastewater, which in the countryside did not include sewage, did not seem to have any impact. The state inquiry of 1942 noted that the regulation from 1919 "does not appear to be effective" [25] in ensuring a good situation with regard to hygiene. In terms of wastewater treatment, discharging the wastewater to the nearest watercourse was considered sufficient. A suggested but rarely applied solution for further treatment when it was not economically reasonable, due to the distance, to discharge wastewater to watercourses, was to use bottomless sludge separators to "defuse the wastewater" [25]. Treatment systems, such as one- and two-chambered sludge separators, which existed at the time, were generally not an imposed requirement [25]. These types of OSSs were only considered necessary if a WC was installed and when wastewater was produced in more densely populated areas, i.e., in outskirts of cities and population centers or "row"-villages. From the state's perspective a far-reaching introduction of WCs was at that time (1942) not seen as desirable in the countryside, foremost because of the benefits and lower health risks of the traditional way of using latrines and spreading excrements on farmland [25].

However, the distinct expansion of WCs into Swedish homes in the decade that followed, without subsequent treatment steps, gave rise to water pollution [27]. According to Rosén and Rosén [24] the experiences of the epidemics of 1946-1947 were important motivators for the stricter rules imposed in 1956, requiring three-chambered sludge separators, which improved the treatment of foremost pathogens. At this time the county administrations were given the authority to oversee the developments in the countryside. The changes in the 1958 health protection regulations implied requirements on a declaration before installing wastewater systems, and that the authorities thereby gained control already at the installation stage [6].

In summary, before the 1950s, sewage and wastewater handling was formally a largely unregulated area in the countryside. Tradition and local knowledge were used when building farm-level systems for handling water and latrines. The processes of changing the handling of water and sewage in the cities preceded a similar transformation in the countryside. Hygiene concerns, increased convenience for homeowners, and changed expectations regarding toilets, made the WC a desirable solution in the broader society and with time also in the countryside. The unspecific rules of the 1940s and 1950s created a space for action for individual homeowners and other actors having knowledge of how to install the systems. Further, in the absence of specific rules and enforcement capacity, it was possible for individual homeowners to install WCs, without much notice taken by the authorities. What, however, initiated technological change and what made WCs and water-based treatment systems take off? As described, actors from the established, primarily urban, sphere such as the media, middle-class citizens and others who had already experienced improved material welfare, and governmental agencies were in favor of making the countryside follow the example of the cities. At first, this was in conflict with the interest of the homeowners who did not seem to have seen the benefits. Homeowners could however not resist the thrusts, which came from many directions. However, homeowners must soon have realized the convenience that an indoor WC brought. Returnees, guests and others from the cities must have exerted pressure on the countryside residents and been an important carrier of technology expectations and norms from the cities. Once the rural homeowners adopted the new ideas, tensions were resolved and instead there was a relatively high coordination and alignment between activities and agendas of rural homeowners, governments, authorities, and established spheres. 
The government introduced rules that prescribed homeowners to have basic treatment in the form of a sludge separator when installing a WC. Local health protection committees were given the task of overseeing the implementation of these rules and an obligation for homeowners to apply for a permit to install an OSS gave the committees a means to do so. That way the role of local knowledge and traditions was replaced by the authorities' knowledge and rules for structuring homeowners' actions. The technology was also fairly rudimentary and while the installation of pipes required labor, the installation could be handled locally, without much assistance from trained contractors.

During this era, the decades after World War II, the government became a relatively stronger player, not least because of industrialization and the increasing tax revenues that followed. Due to a combination of the political climate and the economic capacity, governmental interventions were possible. Importantly, the government intervened and subsidized the construction of water and sewage handling systems in rural areas, giving homeowners the economic capacity to embrace the new technology. Homeowners and others in the countryside who may have objected to this development were not sufficiently large in number to bend the development path, e.g., the use of other technologies. Thus, when using Mahoney and Thelen's theory of incremental change we interpret the quite abrupt technological-institutional change as being rooted in activities starting several decades before. Several actors used change strategies that served their own differing interests but despite this they all acted in ways that resulted in a coherent development of OSS. It was a combination of an enabling political context at the landscape level, self-motivated homeowners, and government interventions that led to the expansion of piped water, WCs, and the use of sludge separators as the principal treatment process in Swedish countryside homes. This implied the birth of a new socio-technical configuration [8] from the 1940s with piped water and WCs as dominant technologies. However, as WCs replaced latrines and only rudimentary technologies were applied, the nutrient capture capacity of OSSs decreased and nutrient loads increased drastically, as illustrated in Figure 1 (see Section 1).

\subsection{Environmental Protection Concerns Becomes a Second Driver-the 1960s to 1990s}

The rapid expansion of water and wastewater systems in both the countryside and the cities made polluted water an increasingly pressing issue, now situated in a context of broader environmental concern. Until the 1960s the large majority of installed treatment systems in the countryside were using, at best, different variations of sludge separators with low nutrient retention capabilities. Concerns regarding environmental pollution led to the introduction of the environmental protection legislation (EPL: in Swedish Miljöskyddslagen) in 1969 and initiated the environmental management in Sweden [29]. The EPL restricted the emission of wastewater and also required permission for installation of sewage systems. According to Christensen [6], this implied that the burden-of-proof increased for the individual homeowner. Moreover, for the first time all homeowners were clearly covered by the legislation and not only homeowners who were setting up new sewage systems. Besides the introduction of EPL the control functions of authorities were strengthened and the municipalities were given the task to inspect OSSs, earlier done by the county administration. However, the local environmental authorities could only interfere when damage occurred that could be linked to an existing wastewater system. 
With the new legislation of 1969 OSSs had to meet both environmental and health protection aims. The existing rules from 1962 implied that simpler types of infiltration beds were required besides sludge separators. These rules are in essence still valid [30] having been adjusted first in 1974 [31], and once again in 1987 [32], and with these stricter rules on construction, materials, and dimensioning, the nutrient capture capabilities of infiltration-based technologies was slowly improving.

One effect of the legislation was that new houses, permanent homes as well as summer homes, were equipped with infiltration-based treatment technologies. Many of today's existing Swedish OSSs were installed during this and the previous period and are still in use [5]. In places where conditions did not allow infiltration, e.g., because of too fine or thin soils, or where the population density was high, such as in many summer home areas, closed tanks were a relatively common solution. However, the government's efforts were not directed at the existing, and aging, OSSs, likely because there were other larger and more obvious sources of water pollution, such as the municipal wastewater treatment plants (WWTPs) and large paper and pulp industries that were largely lacking effective treatment steps at the beginning of the 1970s [7]. An indication of where the money flows were directed is that the government spent about 1.5 billion SEK on municipal WWTPs in the 1970s [7], while no corresponding effort was made directed at mitigating nutrient loads from OSSs.

Of relevance for the development of OSSs was also the phenomenon of Swedes obtaining summer homes, a trend taking place as people got more summer vacation and increased "consumption space" in the 1950s and the 1960s [33]. For instance, during the 1960s about 160,000 summer homes were built. In itself this change did not have much influence on environmental loads because of the relatively low utilization of the summer homes and the fact that many were constructed with latrines. However, since the 1960s mobility has increased due to development of the transportation system and cities have sprawled. Summer homes that were once perceived as located far from cities have become attractive to use as permanent homes. Demands for more comfortable living have grown stronger which have led to summer homes being equipped with piped water and WCs, and hence water-based treatment technologies. Further, in the cases where abandoned permanent homes were transformed to summer homes following the urbanization process of the 1940s to 1960s the existing system for handling sewage was in many cases the rudimentary handling systems applied up to the 1960s. The authorities did not neglect these developments. Already at the beginning of the 1970s, guidance was given regarding which technology to use in summer homes, favoring dry solutions [34]. Today 135,000 are equipped with urine separation technologies [35]. Towards the end of the 1970s there were also inquiries aimed at finding solutions to the issue of OSSs in summer homes in transition to permanent homes, e.g., [26,36,37]. In some contrast to this, in the cases where closed tanks have been used, the environmental loads have remained relatively low since the sewage has been collected and transported to the municipal WWTPs, which have seen increasing nutrient removal capacities since the 1960s and particularly from the 1970s [7].

In summary, the 1960s and 1970s were marked by growing environmental concerns that translated into governmental action and further institutional arrangements and regulation of wastewater. The rules regarding the application of especially new OSSs came to embrace both health and environmental concerns. From a technical and environmental perspective these changes explain the break around 1975 of the negative trend for nutrient removal capacity, as Figure 3 shows. An important technical factor is also that municipal WWTPs have shown increasing nutrient capture rates since the 
1970s. Since the sewage collected from closed tanks and treated at the municipal WWTPs is a relatively common solution this may have influenced the overall nutrient capture capability of OSSs.

Figure 3. The diffusion of water closets and the associated overall trend of phosphorous capture capability for Swedish OSSs between 1945 and 2010. Assumptions and calculations are attached as Supplementary Material.

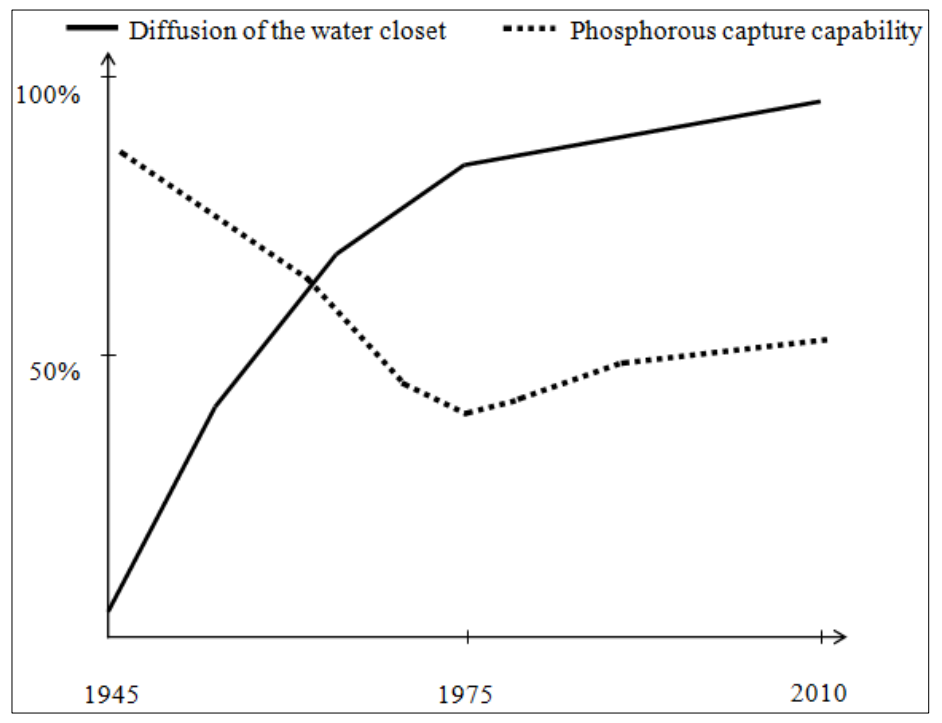

However, several circumstances made the long-term environmental gains rather small. Homeowners could continue to use more rudimentary treatment technologies since they were not subjected to inspection. The technical lifetime of the dominant technology (sludge separator combined with an infiltration bed or compact filter) was unknown at the time of installation and has been shown to be limited, cf. [16,38]. Further, WCs replaced latrines in rural and in summer home areas on an increasing scale, creating conditions that were difficult for municipalities and environmental protection authorities to address. This last factor implied that landscape-level processes, in this case the broad transformation of summer homes to permanent homes as part of sprawling cities and changed user demands, gave rise to changes in some of the elements at the regime level even though the result was not a complete change of existing OSSs, nor did the new technologies diffuse beyond their initial niches. For instance, closed tanks did not replace existing OSSs and even though urine separation technologies have become common in summer homes [35], this technology has not made it beyond this niche to permanent homes [5].

The origin of the technology-specific rules was the increasing knowledge about environmental impacts, discoveries of water quality problems, and rising environmental concerns when scientific knowledge became accepted on a broader scale. The 1960s to the 1990s was a period where national government strengthened environmental institutions, introduced more specific laws, and strengthened enforcement capacity by creating local public health and environmental protection authorities. The technology-specific rules gave certain actors, e.g., those producing components and installing sludge separators, a position to act while restricting the room for action of other potential suppliers. For most users the change in treatment technology did not create any tensions with their expectations or daily routines involving the technology. The "interface" (the tap, the WC etc.) to the sewage 
handling system remained essentially the same, at least in the cases of newly constructed houses. In cases where the change of technology implied a changed "user interface", most prominently when latrines were turned into WCs, this was in line with users' expectations of the new technology and implied, as desired, more convenient systems. In both cases it was in the interest of homeowners to install these specific technologies, that is, piped water, WC, and further means of getting rid of the wastewater from the lot. From this perspective it is also logical that there was no major state aid aimed at easing investments in OSSs similar to the previous decades-it was not needed because of strong user desires for WCs.

Compared to the previous period, which was marked by reconfiguration of many system elements and much activity on several administrative levels, the period from the 1960s and onwards is marked by stability. Technological changes occurred not on the large-scale but in pockets, i.e., when summer homes were built or when summer homes were transformed to permanent homes. Though environmental concerns grew in society this did not lead to major technological changes. The treatment technologies applied remained essentially the same, based on the WC and sludge separators, and were not changing very much during the period besides slight changes in the dimensioning of treatment system components. The ST system and institutional elements therefore followed a path defined by the application of certain types of treatment technologies, which were embedded in a configuration including users' expectations and routines, and formal rules and guidance that defined appropriate treatment technologies. The institutions that were built-up during the period and the rules that were applied were continuously built on the previous ones-new structures were layered [11] on previous ones and did not imply tensions between, e.g., actors or other aspects of the socio-technical system. Also, the institution-building activities were directed at other sources to the nutrient load problem, unintentionally reducing the interest in OSS and not focusing on efforts such as enforcement capacity-building that could have altered the development path for OSS. Therefore, despite a growing concern for the environmental impact of wastewater and incremental institutional changes, environmental outcomes did not improve correspondingly.

\subsection{Broadening Environmental Concerns and an Emphasis on Function in the $1990 \mathrm{~s}$}

In the 1980 s and the 1990 s concerns for the environment increased, e.g., as resource and pollution problems were increasingly discussed, cf. [39]. To cycle nutrients, including those from the sewage, became increasingly important at the political level, even though it had been highlighted already in the early 20th century [20,21]. Also, after the Rio UNCED conference in 1992 there was an emphasis on making people more involved in environmental management, in line with the ideas of Agenda 21. As a response to the Waste Water Directive, inspection campaigns were run in the 1990s. There is anecdotal evidence of inspection campaigns in several municipalities along the Swedish east coast, using informative means of persuasion, which had poor effect in terms of homeowners improving their OSS [40]. One of the reasons was the limited judicial possibility to prescribe homeowners to change malfunctioning OSSs, which was in contrast to the possibilities when new houses were constructed. The transformation of summer homes to permanent homes also continued during this period. Until the 1990s, basically the same treatment technologies were required [31,32]. Some municipalities introduced local building regulations that restricted homeowners to only apply OSS techniques that enabled nutrient cycling 
when constructing new houses [41]. This implied that some type of composting toilet or urine separation system was the only technology allowed. Another local building regulation was the ban against closed tanks imposed on homeowners renovating or building new houses [42].

The difficulties in implementing the OSS legislation were acknowledged by the national government who took measure through the environmental code (EC: in Swedish Miljöbalken) that came into force in 1999, gathering most of the existing environmental legislation applicable to wastewater systems, cf. [6]. Importantly, the code emphasized the function of OSSs in terms of, e.g., their nutrient capture capability instead of a prescribed required technology. Further, the EC stipulated that sustainable development aspects, including nutrient cycling should determine protection levels that in turn influenced the requested degree of treatment. Importantly, the EC made it possible to place injunctions on all homeowners with existing OSS (i.e., not only in cases where new houses were built) to change the system. The code also emphasized the consideration of national environmental goals, adjacent regulatory structures, and agreements decided on an international level, including the consideration of Natura 2000 areas, and to include goals in accordance with the Water Framework Directive and the Baltic Sea Action Plan in the inspection practice. Christensen [6] suggests that the new EC enables local health and environmental protection authorities (HEPA) to place stricter requirements than the earlier legislation. From the new code, guidance was developed in 2006 [43] suggesting two levels of environmental protection depending on the sensitivity of the recipient waters and associated nutrient capture norms, where the higher level of protection implies stricter requirements than ever before. In practice, the implication of a high level of environmental protection is that sludge separators with subsequent infiltration or filter beds are no longer an acceptable solution. Consequently, specific technology is not prescribed any more, since the minimum requirement is determined by the sensitivity of the nearby environment. However, there is room for deviations since the HEPA is to balance the more far-reaching intentions of the regulations, i.e., meeting targets set on national and international levels, with reasonableness of the consequences for individual homeowners. The government introduced a tax reduction in 2009 as a subsidy to support homeowners refurbishing their houses [44]. This tax reduction halves the labor cost and if applied to an improvement of an OSS a total cost reduction of approximately $10 \%-30 \%$ is achieved (which is less than the subsidies in the 1940s and 1950s).

The emphasis on the technology-neutral "function" of OSS instead of specifying a minimum required technology is important since it opened up a variety of technical solutions that fulfill the specified function. Thus, if rules can be flexibly interpreted this gives actors more room to act, both in line with the intentions of the rules but also beyond the original intentions. Certainly, there was technological development already in the 1960s towards more advanced treatment systems and the modern type of compact treatment plants came in the late 1980s [45]. However, other technologies than the minimum required technology specified through the regulation were still not applied on a large scale [5]. The legislation from 1969 prescribed treatment corresponding to more far-reaching treatment than a three-chambered sludge separator, which in practice implied septic tank systems-a three-chambered sludge separator combined with soil infiltration or compact filter. Several factors can explain the changed legislation. The limited success of previous legislation in terms of improved OSSs, which was apparent since at least the late 1970s but certainly in the early 1990s [36,37,46], was likely also a driving force for the government to make a change in the regulations "to try something 
new". The emphasis on technology-neutrality is certainly aligned with an ideological move towards a preference for market solutions, relying more on private initiatives and less on state interference. Importantly, the emphasis on function is also aligned with one of the institutional building blocks of the European Union, the EU Single Market Act, which came into force in 1993. The latter brings several factors that were not previously affecting the institutional development and adoption of various treatment technologies, when companies can act across national borders. Furthermore the inclusion of the CE conformity marking, containing a material performance declaration, nowadays clearly influences the institutional development in the case of the Swedish OSS [47].

During the 2000s the activities of local environmental authorities have certainly increased, and a majority of the municipalities have inspected OSSs to some extent [5]. However, the rate of inspections has been deemed insufficient compared to the large number of homeowners who need to improve their systems [48]. With the current pace of inspection in Sweden it would take about 80 years just to change currently deficient OSSs [49]. Until year 2000 few homeowners with an existing OSS were forced to change the OSS and did not do so, as evidenced by today's large share of the technologies that were dominant already in the 1940s-1970s [5]. Furthermore, a majority of the systems installed after the 1960s have a decreasing treatment function with time, which adds to their poor environmental performance, cf. [38]. In the wider system there has also been increased activity, in that companies have entered the market with new products and gained market shares in the last 10-20 years [50,51]. Further, associations have been formed to capture the interests of different OSS actors, such as compact treatment plant manufacturers and installers (backhoe operators). Municipalities formed the national network Avloppsguiden in 2004 to support rule enforcement and harmonization of the requirements imposed on homeowners between municipalities. This network has with time also evolved to support homeowners in choosing OSS, and the entrepreneurs installing OSS.

In summary, from around the 1990s to the 2010s a set of changes in the character of institutions, as well as in the political context changed the rules of the game. Changes in market institutions (e.g., EU Single Market Act and national adaptations) make it possible for actors who operate across national boundaries to attract resources and use their position on one market when entering another market. This is certainly the case for many treatment system manufacturers for which Sweden is not their biggest market [51]. This institutional change which was external to the OSS regime reduced the possibility of keeping the previous technology-specific rules. By merging functional requirements with previous legislation and using the existing HEPAs to enforce the new legislation, the government could avoid the tension with the new market institutions and still keep, in principle, a high ambition level concerning environmental sustainability. Thus, in principle, the legislation changes gave the HEPAs power to judge the legality of the growing number of technologies on the market and to check that all homeowners continuously have well-functioning OSS. At the same time, the new legislation was not followed by more resources given to the HEPAs. The focus on environmental sustainability made some municipalities promote nutrient cycling systems in new permanent homes. Overall, the enforcement actions have been limited. 


\section{Discussion}

In addition to using the MLP as a theoretical perspective in our analysis we used Mahoney and Thelen's [11] theory of incremental institutional change as a complementary perspective to show how both periods of institutional stability and institutional changes are enacted by specific actors. According to this theory the roots of institutional change are found in the power-distributional implications of institutions. A combination of the character of the institutions and political context gives actors certain room to enact institutional stability and change.

Analyzing the case at hand with this theoretical framework we see, first, that the fact that rules are always imprecise allows actors room to act partly beyond the institutional realm in ways that might challenge the intention of the existing rules. In the first era, formal rules regarding how to organise sewage treatment and law enforcement capacity were largely missing. Since there were actors who strongly desired change (hygiene doctors, homeowners returning to the countryside, with time countryside residents, guests and tourists from cities) and it was possible to install systems without much technological know-how, a quite rapid technological change was possible, which preceded institutional changes to control unintended health consequences related to poorly controlled OSS. When the large-scale transformation of OSS was initialized, the government managed to introduce the first OSS rules specifying treatment technology. Further, the government introduced financial aid, which increased homeowners' opportunities to install WCs and sewage treatment systems. Thereafter the rules turned recurrently stricter and the enforcement capacity of the HEPAs was strengthened. Broadening environmental concerns led to legislative changes in 1999 which implied a substantial change in the character of institutions, when functional requirements of OSSs were introduced. This time, compared to previous rule changes introduced by the government, the government had to adapt their change strategies to a partly new context by which market actors have derived relatively more power due to the introduction of free market institutions. The full implications of this late rule change are yet to be seen, but it has certainly opened up the way for market actors to define the development path. At the same time, the emphasis on function put pressure on homeowners to continuously ensure the performance of their OSS. The HEPAs have now got a more complex enforcement task since they have the authority to and should judge the environmental performance of existing and new OSSs. Hence, the institutional character and the political context matters for technological change since these dimensions span the space of action for ST actors, and constrain what different actors can do.

Second, the extent to which certain actors have the ability to maintain an institutional status quo depends on how they are empowered by institutions. For instance, this helps to explain why municipalities were able to not enforce rules between 1960 and 1990 and why there were only incremental rule changes. In this time period, there was no pressure from within the public administration to control the enforcing municipal inspectors. Rather, the municipalities' monopoly to govern local issues came to overrun the national interest of environmental protection. Further, the technology-neutral rules focusing on the function of OSSs, introduced in 2006, was a feasible solution in a context of strong defenders of status quo (the homeowners who did not want to spend money), and strong forces for change (entrepreneurs wishing to sell more advanced OSSs). Strategies that worked for national agencies were those that were reasonable from an environmental point of view, accepted by government because it fitted in the context of promoting market solutions, and by 
entrepreneurs who could sell or install OSS components. Defenders of status quo can thus be found at different levels of the public administrations (there are rule systems within these organizations) but are most likely found outside, that is, they are actors directly affected by the rules implemented by the public administration. Thus, the concept of level of discretion in implementation is not only valid for the relation between the public administration and the private actor, but also for actors at different levels of the administration, such as the level of discretion in implementation shown by the national and county level administration towards the municipality. We have not focused on these possible sources of incremental institutional change, but highlight them since such weak links between administrative levels may partially explain the lacking enforcement by HEPAs. Other defenders of institutional status quo are indirectly affected but may be very influential in the change process, i.e., the consequences of institutional change may be liked or disliked (e.g., technology suppliers or installers may gain or lose from a change) and being able to do this in rule change processes implies a more than average ability to influence the direction. For instance, several interest groups connected to the OSS suppliers and installers participated actively in the recently finished official inquiry on policy instruments to increase the compliance levels among homeowners with OSS [52].

From an environmental point of view the outcome of technological and institutional developments was first detrimental when nutrient loads increased, albeit being the unintended consequences of deliberate actions to improve living conditions. However, the negative nutrient load trend seems to break around the mid-1970s, due much to the formal rules introduced in the 1950s (for public health protection reasons) and then made stricter several times from the end of the 1960s to today (i.e., for environmental protection reasons). Despite these incremental institutional and technological developments further improvement in environmental outcome is not yet seen on the large scale, even though the number of inspections has increased in the last 5-10 years [52] which we assume to have had the effect that more homeowners have improved their OSS. The rate of inspections and changing OSSs compared to the number of poorly functioning OSSs is deemed to be low [52]. As we have illustrated in the case, current institutional developments (i.e., in Sweden and in the EU) and an alignment with an ideological move towards market-driven solutions also for environmental problems, are allowing market actors to play a larger role in the OSS change process. There are both positive and negative aspects of such a trend. For instance, on the positive side, the rules are formulated to allow for more flexible interpretation in terms of technological development, which could open up innovation. Further down the road there could be more options for homeowners and competition could at least theoretically lower prices. On the negative side, both homeowners and enforcing authorities run the risk of lacking knowledge about the fit and performance of OSSs in specific situations to make the informed decisions needed to make environmentally benign decisions. Further, a question is whether enforcing authorities are able to act to ensure that technological developments are in line with formal rule intentions (i.e., ensure environmental protection). If enforcement is an important aspect of adoption of new technologies at the level of the user in the case of OSS, are increasing activities among market actors met by a parallel distribution of resources to HEPAs, which are currently the rule enforcing actors in Sweden? The legitimacy of institutional and technological developments aimed at environmental protection from users is another issue here. We agree with Kemp and Van Lente [15] that it is important to note that sustainability challenges not only involve structural aspects as the development of new artifacts and changes in regulations, but also changes in "user criteria" that reflect 
user norms and the practices the artifacts are embedded in. User criteria were certainly important in the case of OSS, in particular in the 1940s when the WC was introduced. Because slow-moving processes at landscape level were aligned with institutional arrangements at the regime level and changing user criteria at the application level (the "interface") the technology was spread quite fast. User criteria are still important and explain resistance against technologies such as urine separation, which are more apt for nutrient uptake and at the same time avoid nutrient loads. Technology suppliers and installers will not object to the recent rule changes but act in line with the environmental legislation, albeit being interested in profit rather than environmental protection. Still, the users (at least the majority of Swedes) must accept that homeowners in general have to face the relatively high up-front costs associated with ensuring well-functioning OSS. Thus, the governance of Swedish OSSs has grown increasingly complex which, makes any statements regarding environmental outcomes of recent technological and institutional developments uncertain.

\section{Conclusions}

Acknowledging that nutrient loads from OSSs are relatively high in industrialized countries, this paper analyzes the historical development of OSSs in Sweden. The building up of institutions, technological change, and the resulting environmental outcome in terms of the nutrient capture of Swedish OSSs is described for three separate eras. During the first, especially during the period from the mid-1940s to the beginning of the 1960s, hygienic concerns, large-scale home improvement programs, and aspirations for higher living standards had the effect that almost half of all countryside homes got piped water and wastewater and changed from latrines to WCs. Thus, most of this large-scale transformation of OSSs occurred during a period when the water-based sewage systems were not constructed to achieve environmental protection. In the second era, from the late 1960s to the 1990s, environmental concerns led to stricter OSS regulations and slowly increasing overall nutrient capture capability of OSSs. However, the new rules implied only incrementally improving treatment technologies. During the third era, starting in the 1990s, rules have been strengthened, but homeowners have nevertheless not changed OSSs on a large scale. The main reason behind this situation is that a series of "unintended" consequences of homeowners' deliberate actions and of interventions during earlier eras has led to a stable institutional-technological configuration where water-based treatment technology became the norm (both formally and informally), challenging the introduction of technologies able to reach higher nutrient capture capabilities. While hygiene concerns at the collective level were aligned with homeowner aspirations-user expectations were "moving in the same direction" as the wider system [13], during the first stage, it is not the case for environmental concerns during the 2nd and 3rd stages. Furthermore, no strong interventions similar to those in 1945-1960 have occurred. This implies that the sequencing of events was important [10], meaning that the series of choices made foremost between the 1950s and 1990s caused both institutional and technical lock-in effects that have been increasingly difficult to break out from. The consequence is decreased nutrient capture capability in Swedish OSSs comparing 2010 to 1945.

The government during the 20th century has certainly gained control over the development through the introduction of enforcing authorities and increasingly strict rules. However, their transformative capacity, as "change agents", has varied over time and they have not been capable of controlling all 
homeowners. Hence, even though the OSSs as pollution sources were recognized the capacity of governments did not, using the terms of Ness et al. [53], cover the whole "domain of causes" of the environmental problem. In response to the stalemate of stagnating OSS performance, the emphasis on function can be seen as the governance-oriented response to let market actors into the process of defining technological development. A combination of factors, including wide-spread expectation of water-based OSS treatment technologies among actors and the strategies of technology suppliers and other market actors, will most probably be influential in shaping future nutrient loads from OSSs.

\section{Supplementary Materials}

Supplementary materials can be accessed at: http://www.mdpi.com/2071-1050/5/11/4706/s1.

\section{Acknowledgments}

The work was financially supported by the Swedish research council FORMAS and the Bank of Sweden Tercentenary Foundation (Stiftelsen Riksbankens Jubileumsfond).

\section{Conflicts of Interest}

The authors declare no conflict of interest.

\section{References}

1. Wallin, A. Factors Influencing Actors at the Interface between the Socio-Technical and the Ecological Systems: The Case of on-Site Sewage Systems and Eutrophication; Chalmers University of Technology: Göteborg, Sweden, 2012.

2. Helsinki Commission. Eutrophication in the Baltic Sea-an Integrated Thematic Assessment of the Effects of Nutrient Enrichment and Eutrophication in the Baltic Sea Region; Report No 115B; Helsinki Commission: Helsinki, Finland, 2009.

3. Swedish Environmental Protection Agency. Näringsbelastning på östersjön och västerhavet: En sammanställning av beräkningar mellan åren 1985-2006 (in Swedish); Report No 5965; Swedish Environmental Protection Agency: Stockholm, Sweden, 2009.

4. Brandt, M.; Ejhed, H. TRK transport-retention-källfördelning: Belastning på havet (in Swedish); Report No 5247; Swedish Environmental Protection Agency: Stockholm, Sweden, 2002.

5. Ek, M.; Junestedt, C.; Larsson, C.; Olshammar, M.; Ericsson, M. Teknikenkät—enskilda avlopp 2009 (in Swedish); SMED Report No 44; Swedish University of Agricultural Sciences and Swedish Meteorological and Hydrological Institute: Norrköping, Sweden, 2011.

6. Christensen, J. Enskilda avlopp - miljöbalken har ändrat de rättsliga förutsättningarna. In Miljörätten i förändring-en antologi (in Swedish); Björkman, U., Michanek, G., Eds.; Iustus Förlag: Uppsala, Sweden, 2003; Volume 36, pp. 153-230.

7. Swedish Environmental Protection Agency. Wastewater Treatment in Sweden; Swedish Environmental Protection Agency: Stockholm, Sweden, 2009.

8. Geels, F.W. Technological transitions as evolutionary reconfiguration processes: A multi-level perspective and a case-study. Res. Policy 2002, 31, 1257-1274. 
9. Rip, A.; Kemp, R. Technological Change. In Human Choice and Climate Change; Rayner, S., Malone, E.L., Eds.; Battelle Press: Columbus, OH, USA, 1998; Volume 2, pp. 327-399.

10. Geels, F.W. The multi-level perspective on sustainability transitions: Responses to seven criticisms. Environ. Innov. Soc. Transit. 2011, 1, 24-40.

11. Mahoney, J.; Thelen, K. A theory of gradual institutional change. In Explaining Institutional Change. Ambiguity, Agency, and Power; Mahoney, J., Thelen, K., Eds.; Cambridge University Press: New York, NY, USA, 2010.

12. Geels, F.W. The hygienic transition from cesspools to sewer systems (1840-1930): The dynamics of regime transformation. Res. Policy 2006, 35, 1069-1082.

13. Pierson, P. Politics in Time: History, Institutions, and Social Analysis; Princeton University Press: Princeton, NJ, USA, 2004.

14. Pierson, P. Increasing returns, path dependence, and the study of politics. Am. Polit. Sci. Rev. 2000, 94, 251-266.

15. Kemp, R.; van Lente, H. The dual challenge of sustainability transitions. Environ. Innov. Soc. Transit. 2011, 1, 121-124.

16. Eveborn, D.; Kong, D.; Gustafsson, J.P. Wastewater treatment by soil infiltration: Long-term phosphorus removal. J. Contam. Hydrol. 2012, 140-141, 24-33.

17. Smith, A.; Stirling, A.; Berkhout, F. The governance of sustainable socio-technical transitions. Res. Policy 2005, 34, 1491-1510.

18. Capoccia, G.; Keleman, R.D. The study of critical junctures: Theory, narrative, and counterfactuals in historical institutionalism. World Polit. 2007, 59, 341-369.

19. Socialstyrelsen. Bostäder och hushåll: Enligt allmänna bostadsräkningen 1945 och därtill anslutna undersökningar (in Swedish); Socialstyrelsen: Stockholm, Sweden, 1952.

20. Wetterberg, O.; Axelsson, G. Smutsguld \& dödligt hot (in Swedish); Göteborgs Renhållningsverk: Göteborg, Sweden, 1995.

21. Bjur, H. Vattenbyggnadskonst i Göteborg under 200 år (in Swedish); Rundqvists Boktryckeri: Göteborg, Sweden, 1988.

22. Nordström, L. Lort-Sverige (in Swedish), 2nd ed.; Kooperativa Förbundets Bokförlag: Stockholm, Sweden, 1938.

23. Bergholm, G.; Kjellin, U. Dass: En undersökning av det hemliga rummet (in Swedish), 2nd ed.; Fischer \& Company: Rimbo, Sweden, 2003.

24. Rosén, B.; Rosén, E. Lortsverige: 50 år efter Lubbe Nordström (in Swedish); Svenska kommunförbundet, Kommentus gruppen distributör: Stockholm Älvsjö, Sweden, 1988.

25. Statens Egnahemsstyrelse. Egnahemsstyrelsen; med utredning och förslag angående vattenförsörjning och avloppsförhållanden på landsbygden (in Swedish); Statens Egnahemsstyrelse: Stockholm, Sweden, 1942.

26. Bjur, H.; Malbert, B. Lokala lösningar för vattenförsörjning och avlopp, LOVA: Planering, genomförande och teknik (in Swedish); Swedish Environmental Protection Agency: Solna, Sweden, 1982.

27. Statens folkhälsoinstitut. Undersökningar rörande små avloppsreningsanläggningar. 1950 års utredning om små avloppsanläggningar. In Statens Offentliga Utredningar (in Swedish); Statens folkhälsoinstitut: Stockholm, Sweden, 1955. 
28. Lagerqvist, M. Torpets transformationer: Materialitet, representation och praktik från år 1850 till 2010 (in Swedish). Ph.D. Thesis, Kulturgeografiska institutionen Stockholms Universitet, Stockholm, Sweden, 2011.

29. Lundqvist, L.J. Miljövårdsförvaltning och politisk struktur (in Swedish); Bokförlaget Prisma/Föreningen Verdandi: Uppsala, Sweden, 1971.

30. Swedish Environmental Protection Agency. Små avloppsanläggningar. Hushållsspillvatten från högst 5 hushåll (in Swedish); Swedish Environmental Protection Agency: Stockholm, Sweden, 2003.

31. Swedish Environmental Protection Agency. Små avloppsanläggningar: Rening av spillvatten från enstaka fastigheter (in Swedish); Swedish Environmental Protection Agency: Solna, Sweden, 1974.

32. Swedish Environmental Protection Agency. Små avloppsanläggningar: Hushållsspillvatten från högst 5 hushåll (in Swedish); Swedish Environmental Protection Agency, Liber distribution: Solna, Sweden, 1987.

33. Tell, J. Älskade fritidshus: Fakta och finurligheter om ett svenskt fenomen (in Swedish); Bokförlaget Dagens Nyheter: Stockholm, Sweden, 2002.

34. Danielsson, K. Klosetter för fritidshus (in Swedish); Seelig: Stockholm, Sweden, 1970.

35. Kvarnström, E. Urine Diversion : One Step towards Sustainable Sanitation; Stockholm Environment Institute: Stockholm, Sweden, 2006.

36. Bjur, H.; Jerkbrant, C.; Malbert, B. Alternativa system för avfall, vatten och avlopp i områden med äldre bebyggelse (in Swedish); Statens råd för byggnadsforskning: Svensk byggtjänst: Stockholm, Sweden, 1977.

37. Bjur, H.; Jerkbrant, C.; Malbert, B. Det löser sig: Hur man löser problem med avfall, vatten och avlopp $i$ äldre bebyggelseområden (in Swedish); Statens råd för byggnadsforskning: Svensk byggtjänst: Stockholm, Sweden, 1978.

38. Eveborn, D. Kvantifiering av fosforläckage från markbaserade avloppssystem (in Swedish); Swedish Agency for Marine and Water Management: Göteborg, Sweden, 2012.

39. World Commission on Environment and Development. Our Common Future; Oxford University Press: Oxford, UK, 1987.

40. Wallin, A. Health and environmental protection authority inspector, Västervik Municipality, Sweden, Personal communication, 10 March 2010.

41. Wallin, A. Health and environmental protection inspectors, Västervik and Tanum Municipalities, Sweden, Personal communication, 10 March 2010 respectively 24 March 2010.

42. Wallin, A. Health and environmental protection inspectors, Tanum and Kungsbacka Municipalities, Sweden, Personal communication, 24 March 2010 respectively 8 April 2010.

43. Swedish Environmental Protection Agency. Naturvårdsverkets allmänna råd [till 2 och 26 kap. Miljöbalken och 12-14 och 19 §§ förordningen (1998:899) om miljöfarlig verksamhet och hälsoskydd] om små avloppsanordningar för hushållsspillvatten (in Swedish); Swedish Environmental Protection Agency: Stockholm, Sweden, 2006.

44. Ministry of Finance. Skattereduktion för reparation, underhåll samt om- och tillbyggnad av vissa bostäder (in Swedish); Prop. 2008/09:178; Ministry of Finance: Stockholm, Sweden, 2008.

45. Hubinette, M. Tillsyn på minireningsverk inklusive mätning av funktion (in Swedish); County of Västra Götaland: Göteborg, Sweden, 2009. 
46. Swedish Environmental Protection Agency. Vatten, avlopp och miljö: Underlagsrapport till naturvårdsverkets aktionsprogram Miljö '93 (in Swedish); Report No 4207; Swedish Environmental Protection Agency: Solna, Sweden, 1993.

47. Swedish Agency for Marine and Water Management. Delredovisning enskilda avlopp —som avser nya krav $i$ europaparlamentets och rådets byggproduktförordning (EU) $n r$ 305/2011 (in Swedish); Swedish Agency for Marine and Water Management: Göteborg, Sweden, 2013.

48. Swedish Environmental Protection Agency. Handboken små avloppsanläggningar (in Swedish); Swedish Environmental Protection Agency: Stockholm, Sweden, 2008.

49. Swedish Environmental Protection Agency. Återrapportering av mål 4 i regleringsbrevet för år 2008 (in Swedish); Swedish Environmental Protection Agency: Stockholm, Sweden, 2009.

50. Af Petersens, E. Småskaliga avloppsreningsanläggningar-marknadsöversikt över prefabricerade produkter för behandling "i slutet av röret” (in Swedish); Svenskt Vatten: Stockholm, Sweden, 2003.

51. Avloppsguiden and Kunskapscentrum Små Avlopp, Marknadsöversikt. Produkter för enskilt avlopp (in Swedish). Avaliable online: http://husagare.avloppsguiden.se/attachments/download/ 108/Marknadsoversikt_1_1_2011_maj_low.pdf (accessed on 28 June 2013).

52. Swedish Agency for Marine and Water Management. Styrmedel för en hållbar åtgärdstakt av små avloppsanläggningar. Slutrapportering av regeringsuppdrag enskilda avlopp (in Swedish); Swedish Agency for Marine and Water Management: Göteborg, Sweden, 2013.

53. Ness, B.; Anderberg, S.; Olsson, L. Structuring problems in sustainability science: The multi-level DPSIR framework. Geoforum 2010, 41, 479-488.

54. Bostadsstyrelsen. Folk- och bostadsräkningen den 1 november 1960: Redogörelse för folk- och bostadsräkningens uppläggning och utförande (in Swedish); Bostadsstyrelsen: Stockholm, Sweden, 1965.

55. Statistics Sweden. Folk- och bostadsräkningen 1970 (in Swedish); Statistics Sweden: Stockholm, Sweden, 1974.

56. Statistics Sweden. Folk- och bostadsräkningen 1975 (in Swedish); Statistics Sweden: Stockholm, Sweden, 1978.

57. Statistics Sweden. Folk- och bostadsräkningen 1980 (in Swedish); Statistiska centralbyrån: Stockholm, Sweden, 1981.

58. Statistics Sweden. Folk- och bostadsräkningen 1990 (in Swedish); Statistiska centralbyrån: Stockholm, Sweden, 1992.

59. Statistics Sweden. Bostads- och byggnadsstatistisk årsbok 2010 (in Swedish); Statistics Sweden, Publikationstjänsten: Örebro, Sweden, 2010.

60. Statistics Sweden. Utsläpp till vatten och slamproduktion 2008. Kommunala reningsverk, skogsindustri samt viss övrig industri (in Swedish); Statistics Sweden: Stockholm, Sweden, 2010.

(C) 2013 by the authors; licensee MDPI, Basel, Switzerland. This article is an open access article distributed under the terms and conditions of the Creative Commons Attribution license (http://creativecommons.org/licenses/by/3.0/). 